Anna Maria Dolińska

https://doi.org/10.18778/8220-636-4.13

\title{
TEATR DLA NIEWIDOMYCH I SEABO WIDZĄCYCH
}

Jedną z najliczniejszych w Polsce, bo blisko stutysięczną, grupą społeczną, której dostęp do sztuki był przez lata utrudniony bądź ograniczony, są bez wątpienia osoby z dysfunkcjami wzroku. $\mathrm{O}$ tym, że uczestniczenie w wydarzeniach artystycznych ma nadzwyczajną moc łączenia ludzi, rozwijania ich kreatywności, a także, że uczy ono otwartości na innych - nie trzeba już nikogo przekonywać. Podobnie jak bezsporne jest przeświadczenie o dobroczynnym wpływie sztuki na proces rehabilitacji i rewalidacji osób z niepełnosprawnościami. Nie ma dziś wątpliwości co do udziału i znaczenia działań twórczych w emocjonalnym i intelektualnym rozwoju człowieka, a w konsekwencji także w procesie normalizacji życia społecznego i zawodowego ludzi z niepełnosprawnościami ${ }^{1}$.

Jak wiadomo, bierne i czynne uczestnictwo niewidomych w kulturze odbywa się za pośrednictwem dotyku i słuchu. To dotyk właśnie jest w stanie kompensować zdolność widzenia. Warto przypomnieć, że samo zjawisko kompensacji ma ogromne znaczenie w praktycznej działalności osób z niepełnosprawnościami, tak pedagogicznej, jak i rehabilitacyjnej. Ludzki organizm

1 [Literatura krytyczna dotycząca tego zagadnienia jest ogromna, spośród nowszych polskich wypowiedzi (zawierających także bogatą bibliografię przedmiotu) można wskazać np.: Odzyskiwanie obecności. Niepetnosprawność w teatrze i performansie, wybór i oprac. Ewelina Godlewska-Byliniak, Justyna Lipko-Konieczna, Fundacja Teatr 21, Warszawa 2017; Arteterapia i twórczość w przestrzeni psychospołecznej, red. nauk. Anita Stefańska, Uniwersytet im. Adama Mickiewicza, Wydział Pedagogiczno-Artystyczny, Poznań, Kalisz 2015; Osoba niepetnosprawna w procesie rehabilitacji, red. nauk. Hanna Żuraw, Pedagogium Wyższa Szkoła Nauk Społecznych, Warszawa 2014; Arteterapia. Od rozważań nad teoria do zastosowań praktycznych, red. Wiesław Karolak, Barbara Kaczorowska, Wydawnictwo Akademii Humanistyczno-Ekonomicznej, Łódź 2011; Sztuka $w$ życiu i edukacji osób niepetnosprawnych. Wybrane zagadnienia, red. Ewelina Jutrzyna, Akademia Pedagogiki Specjalnej im. Marii Grzegorzewskiej, Warszawa 2003; Wita Szulc, Kulturoterapia. Wykorzystanie sztuki i dziatalności kulturalno-oświatowej w lecznictwie, Akademia Medyczna im. Karola Marcinkowskiego w Poznaniu, wyd. 2 poszerz. i uzup., Poznań 1994 - przyp. red.] 
charakteryzuje bowiem dynamika i zdolność adaptacji do zachodzących zmian. Dysponuje on także pewnymi „rezerwami”, które mogą zostać wykorzystane w przypadku zaburzeń czy defektów. Uruchomione w odpowiedni sposób możliwości kompensacyjne organizmu mogą wyrównać, a nawet zastąpić, uszkodzoną funkcję lub sprawność. U osób niewidomych i niedowidzących jest to kompensacja utraconej czy uszkodzonej funkcji analizatora wzrokowego i przejęcie jej przez pozostałe analizatory (zmysły), wśród których istnieje pewna hierarchia ${ }^{2}$ - jedne $z$ nich mają większe, inne mniejsze znaczenie. U ludzi widzących dominująca rola przypada zmysłowi wzroku, natomiast u osób niewidomych rolę tę przejmuje zmysł dotyku.

W rozwoju filogenetycznym dotyk był bowiem wcześniejszy niż wzrok. Pomimo że stracił on swoją wartość wobec dominacji wzroku, to zachował jednak duże możliwości kompensacyjne, np. w przypadku ślepoty [...]. Drugim pod względem wartości kompensacyjnej zmysłem u niewidomych jest słuch. Wartość ta wynika stąd, że podobnie jak wzrok należy on do tzw. teleanalizatorów, a więc odbierających bodźce, których źródłem są przedmioty i zjawiska nieznajdujące się w bezpośrednim kontakcie z receptorami. Otoczenie jest pełne bodźców akustycznych (słuchowych), które stale oddziałują na zmysł słuchu. Jest to podobne zjawisko jak w przypadku bodźców wzrokowych (wizualnych) ${ }^{3}$.

Kompensacyjną rolę zmysłu słuchu wykorzystuje audiodeskrypcja - technika, dzięki której osoby niewidome i słabowidzące uzyskują dostęp także do treści wizualnych, m.in. utworów filmowych i scenicznych. Wielu tyflopsychologów zwraca uwagę na rolę i znaczenie języka w kompensacji dysfunkcji wzroku. Jest to tzw. kompensacja werbalna czy inaczej słowna, której istota polega na tym, że słowa dostarczają osobom z niepełnosprawnością wzroku tych treści poznawczych, które widzącym zapewnia wzrok ${ }^{4}$. Ludzie niewidomi i niedowidzący mogą otrzymać rozmaite informacje o przedmiotach

2 Za: Tadeusz Majewski, Zagadnienia kompensacji u niewidomych i niedowidzacych, [w: ] idem, Psychologia niewidomych i niedowidzących, Państwowe Wydawnictwo Naukowe, Warszawa 1983, s. 33, https://pl.scribd.com/document/132636388/Majewski-Tadeusz-Psychologia-niewidomych-i-niedowidz\%C4\%85cych-rtf (dostęp:10.08.2017).

3 Ibidem, s. 41, 51.

4 Por.: Tadeusz Majewski, Czy zjawisko kompensacji występuje również u dzieci stabowidzacych?, http://tyfloserwus.trakt.org.pl/viewpage.php?page_id=151 (dostęp: 7.05.2017); Dorothy Bligham, Analiza pewnych aspektów rozwoju niewidomego dziecka, „Materiały Tyflologiczne”, Polski Związek Niewidomych, Warszawa 1980; Tadeusz Majewski, Psychologia... 
i zjawiskach z otaczającego ich świata m.in. za pośrednictwem słownego opisu, wyjaśnień czy instruktażu dotyczącego wizerunku wybranych obiektów. Kompensacja ta opiera się na większym wykorzystaniu funkcji poznawczej mowy. Stanowi jednocześnie uzupełnienie kompensacji percepcyjnej, a więc uzupełnia informacje uzyskane przy wykorzystaniu pozostałych zmysłów. Stosująca kompensację werbalną idea audiodeskrypcji ${ }^{5}$ została przeniesiona także do Polski. Pierwszy publiczny pokaz praktyki polskiej audiodeskrypcji odbył się w roku 1999 na konferencji organizowanej przez Bibliotekę Centralną PZN w Muszynie ${ }^{6}$. Szczególne zasługi w promowaniu i upowszechnianiu w naszym kraju metod werbalnego przekazu treści wizualnych mieli białostoczanie: Tomasz Strzymiński i Barbara Szymańska-Fionik, domagający się równych praw $\mathrm{w}$ instytucjach kultury dla osób niewidomych. To dzięki ich staraniom osoby niewidzące i niedowidzące uzyskały dostęp do świata teatru i filmu. W listopadzie 2006 roku w białostockim kinie „Pokój” zorganizowali oni pierwszy w Polsce pokaz filmowy z audiodeskrypcją wygłaszaną na żywo przez lektora ${ }^{7}$. Sukces tego pierwszego pokazu i liczne telefony od osób pragnących wziąć

5 Audiodeskrypcja, powstała w latach 80 . XX wieku w USA, to technika, która dzięki opisom słownym udostępnia odbiór wizualnej twórczości artystycznej oraz pozwala osobom niewidomym i niedowidzącym poznawać widzialny dorobek kulturalny z zakresu sztuk plastycznych, performatywnych, teatralnych, filmowych i nowomedialnych. Tworzenie opisów audiodeskrypcyjnych polega na werbalnym opisywaniu znaczących dla odbioru dzieł sztuk ich treści wizualnych, np. takich jak: wyobrażenie obrazu, język ciała, wyraz twarzy, przebieg akcji, sceneria, kostiumy. Zwięzłe, obiektywne opisy takich treści pozwalają osobie niewidomej np. podążać za rozwijającym się wątkiem prezentowanej historii czy usłyszeć i zrozumieć to, co dzieje się na scenie lub na ekranie, czy też percypować to, co zostało przedstawione na obrazie, zob: strona Fundacji Audiodeskrypcji: http://www.audiodeskrypcja.org. pl/?start=20 (dostęp: 7.05.2017). [Por. też: Aneta Pawłowska, Julia Sowińska-Heim, Audiodeskrypcja dzieł sztuki. Metody - problemy - przykłady, Wydawnictwo Uniwersytetu Łódzkiego, Łódź 2016, http://www.audiodeskrypcja.pl (dostęp: 10.07.2017) - przyp. red.]

614 listopada 2007 roku odbyło się natomiast pierwsze polskie przedstawienie teatralne z audiodeskrypcją. Dzieci niewidome i słabowidzące obejrzały w Białostockim Teatrze Lalek spektakl Jest królik na księżycu. Autorem i wykonawcą tekstu audiodeskrypcji był aktor Dariusz Jakubaszek. Zob.: Mateusz Ciborowski, Pod lupq: Chodź, opowiedz mi świat, „Pochodnia. Magazyn Społeczny Polskiego Związku Niewidomych” 2010, $\mathrm{nr} 4(871)$, http://pochodnia.pzn.org.pl/artykul/311-pod_lupa_chodz_opowiedz_ mi_swiat.html (dostęp: 10.09.2017).

727 listopada 2006 roku w kinie „Pokój” w Białymstoku odbył się pokaz filmu Statyści w reż. Michała Kwiecińskiego. Zob.: http://www.niepelnosprawni.pl/ledge/x/17995 (dostęp: 7.05.2017). 
udział w podobnych projekcjach pociągnęły za sobą kolejne prezentacje oraz sprawiły, że po audiodeskrypcję sięgnęła m.in. Telewizja Polska, która rozpoczęła taką działalność od udostępnienia w internecie odcinków popularnego serialu Ranczo opatrzonych opisami dla niewidomych ${ }^{8}$. Ewenementem na skalę europejską, a wręcz światową, było zaprezentowanie na 32. Festiwalu Polskich Filmów Fabularnych w Gdyni filmu Świadek koronny z dostępem dla osób z dysfunkcją wzroku9 ${ }^{9}$. Nigdy wcześniej na żadnym wielkim festiwalu filmowym, np. w Cannes, w Berlinie czy w Wenecji, nie udokumentowano tego typu wydarzenia. W projekcji zrealizowanej w czasie 32. FPFF udział brało około 60 osób niewidomych, które dzięki słuchawkom mogły śledzić wydarzenia na ekranie. Od tego czasu audiodeskrypcja zajmuje ważne miejsce w repertuarze gdyńskiego festiwalu. W 2017 roku w ramach jego 42. edycji w Gdyńskim Centrum Filmowym odbyła się branżowa prezentacja systemu AUDIOMOVIE, służącego do obsługi audiodeskrypcji i audionapisów na potrzeby seansów kinowych, pokazów festiwalowych i telewizji. Można więc powiedzieć, że jesteśmy w tym zakresie nie tylko pionierami $\mathrm{w}$ dziedzinie fil$\mathrm{mu}$, ale też na bieżąco reagujemy na zmieniające się możliwości techniczne realizacji audiodeskrypcji.

A co z innymi dziedzinami sztuki, chociażby z teatrem, który już dawno przestał być jedynie przestrzenią prezentacji teatralnych spektakli? Coraz częściej teatr staje się miejscem rzeczywistego artystycznego i społecznego spotkania twórców i odbiorców, przestrzenią ich intensywnego dialogu i dyskusji. Coraz częściej również do dialogu takiego zapraszane są osoby dotychczas w życiu teatralnym uczestniczące jedynie sporadycznie czy okolicznościowo.

8 Od czerwca 2007 roku w telewizji interaktywnej i w TVP udostępniono odcinki serialu Ranczo w reżyserii Wojciecha Adamczyka. Obecnie na stronie Telewizji Polskiej dostępne są kolejne seriale, filmy i spektakle Teatru Telewizji z audiodeskrypcją, a od 1 lipca 2011 roku weszła w życie nowelizacja ustawy o radiofonii i telewizji, która wdraża dyrektywę unijną z 2010 roku, nakładającą na nadawców telewizyjnych obowiązek dostosowania 10 proc. programów do potrzeb osób niesłyszących i niewidomych. W związku z tym programy i filmy z audiodeskrypcją dostępne są również w ofercie stacji komercyjnych, takich jak Polsat i TVN.

9 Świadek koronny w reż. Jarosława Sypniewskiego i Jacka Filipiaka został zaprezentowany na FPFF 17 września 2007 roku. Twórcą i wykonawcą audiodeskrypcji był Dariusz Jakubaszek, aktor, związany z Teatrem „Baj Pomorski” w Toruniu, z Olsztyńskim Teatrem Lalek i z Teatrem 3/4 Zusno. 


\section{Niewidomi w świecie widowisk}

„Widowisko”, „oglądanie przedstawienia”, „widownia” - wiele pojęć związanych z teatrem odnosi się do świata obrazów ${ }^{10}$. Dziś jednak, choć ciągle sporadycznie i nieśmiało, pojawiają się próby organizowania spektakli dla osób niewidomych. Zwykle związane są one z wykorzystaniem audiodeskrypcji. Pierwszy raz technika ta została zastosowana w waszyngtońskim teatrze Arena Stage w 1981 roku. W 1992 roku już ponad 60 teatrów na terenie Stanów Zjednoczonych grało przedstawienia dostępne dla osób z dysfunkcją wzroku, a idea ta szybko przeniosła się do Kanady oraz Wielkiej Brytanii ${ }^{11}$. W polskich teatrach audiodeskrypcja po raz pierwszy zawitała w 2007 roku. Fundacja Dzieciom „Zdążyć z pomocą” podjęła wówczas wspólpracę z Teatrem Narodowym w Warszawie i przygotowano audiodeskrypcję do dwóch spektakli z repertuaru warszawskiej sceny ${ }^{12}$.

Na potrzeby osób z dysfunkcją wzroku zwrócił również uwagę Teatr Powszechny w Łodzi, który jako pierwszy w kraju - i jak dotąd jedyny - zaczął zapraszać te osoby na regularnie przygotowywane dla nich spektakle $\mathrm{w}$ ramach cyklu Teatr dla niewidomych i stabo widzacych. Powszechny, będąc teatrem komediowym o ściśle określonym profilu artystycznym, od lat stara się za pośrednictwem repertuaru - potocznie uważanego za lżejszy - podejmować tematy najważniejsze i mówić o problemach bliskich współczesnemu człowiekowi, swojemu widzowi. W tym celu sięga po różne gatunki komedii i poszukuje nowych kontekstów komediowego rzemiosła, wszystko po to, by przedstawić widowni wielowymiarowość komizmu i śmiechu. Dyrektor Ewa Pilawska, prowadząc Teatr Powszechny, kieruje się zasadą „Teatr blisko ludzi”, dlatego od lat zabiega przede wszystkim o to, by prowadzona przez nią instytucja była jak najbliżej łodzian, również tych, którym trudno dotrzeć do teatru, bądź bywają w nim sporadycznie. W tym celu Teatr podjął wiele unikatowych społeczno-artystycznych inicjatyw, m.in. Spektakle dla osób bezrobotnych, Spektakl dla

10 Por.: Agnieszka Labisko, Integracja $w$ teatrze. Rozmowa $z$ Tomaszem Strzymińskim, http://www.teatry.art.pl/!rozmowy/iwte.htm (dostęp: 29.07.2017).

11 W latach 80. w USA, a w latach 90. w Wielkiej Brytanii audiodeskrypcja weszła do telewizji. W ramach projektu „Audetel” na kanałach iTV i BBC nadawano tygodniowo po kilka programów z dodatkową ścieżką dźwiękową. W latach 90. w Walii pojawiły się również pierwsze seanse kinowe z komentarzami dla niewidomych. Połowa lat 90 . przyniosła natomiast pierwsze filmy z audiodeskrypcją wydawane na kasetach VHS, a następnie w wersji cyfrowej na płytach DVD. Dziś filmy tego typu dostępne są dla niewidomych w wielu bibliotekach i księgarniach w USA, Kanadzie i Unii Europejskiej.

12 Za: Barbara Zarzecka, Kino bez niedomówień, „Pochodnia. Magazyn Społeczny Polskiego Związku Niewidomych” 2009, nr 10(865), http://pochodnia.pzn.org.pl/ artykul/180-kino_bez_niedomowien.html (dostęp: 7.05.2017). 
emerytów, szeroko zakrojoną Edukację teatralna (realizowaną dla wszystkich grup wiekowych), w tym autorski edukacyjny cykl Dziecko w sytuacji, w którym spektaklom teatralnym dla młodych widzów towarzyszą specjalne warsztaty ${ }^{13}$.

Uzasadniając potrzebę rozwinięcia w Teatrze swojego autorskiego projektu - Teatr dla niewidomych i słabo widzących - Ewa Pilawska podkreśla:

Jest we mnie potrzeba tworzenia teatru dla wszystkich. Uważam, że teatr nie powinien być zamknięty, hermetyczny i salonowy. Powinien być otwarty, żywy, powinien pulsować, być w centrum i odważnie podejmować nowe, ryzykowne nawet, wyzwania artystyczne - tworzyć nowe przestrzenie ${ }^{14}$.

Teatr dla niewidomych i słabo widzacych, na początku nazwany Teatrem Czytanym, był i wciąż pozostaje projektem unikatowym w skali kraju i jednym z nielicznych tego typu projektów $\mathrm{w}$ Europie. W przeciwieństwie do realizowanych okazjonalnie przez inne teatry pokazów dla osób z dysfunkcją wzroku, premiery przygotowywane regularnie od przeszło dekady przez Teatr Powszechny w Łodzi stanowią integralny element jego repertuaru.

\section{Teatr dla osób niewidomych}

Jesienią 2005 roku Ewa Pilawska pojawiła się w biurze łódzkiego okręgu Związku Niewidomych z propozycją zorganizowania pierwszego spektaklu. Pomimo ogromnego zainteresowania i entuzjazmu, z jakim inicjatywę przyjęła

13 Spektakle zrealizowane w ramach tego cyklu adresowane są do dzieci i młodzieży, a przygotowane na podstawie współczesnej literatury teatralnej dziecięcej i młodzieżowej uznanych autorów. Sztuki te podejmują ważne dla młodych ludzi tematy, takie jak samotność, brak akceptacji, choroba lub śmierć bliskiej osoby czy odkrywanie swojej tożsamości. Każdemu przedstawieniu towarzyszą specjalnie przygotowane warsztaty, do których prowadzenia Teatr zaprasza specjalistów z różnych dziedzin wiedzy: psychologów, filozofów, seksuologów. Teatr organizuje również specjalne pokazy swoich przedstawień dla dzieci i młodzieży pozostających pod opieką domów dziecka i MOPS-u oraz prowadzi cykliczne warsztaty dla seniorów i młodzieży będącej pod opieką Stowarzyszenia MONAR, dla których stanowią one element resocjalizacji i powrotu do normalnego życia. Jako organizator Międzynarodowego Festiwalu Sztuk Przyjemnych i Nieprzyjemnych przygotowuje także specjalną pulę wejściówek na spektakle, specjalnie z myślą o osobach, których nie stać na zakup biletów w normalnych cenach.

14 Rozmowa autorki z Ewą Pilawską. 
ówczesna prezes Związku Niewidomych w Łodzi Teresa Wrzesińska, obie strony miały obawy czy przedstawienie takie się powiedzie. Apetyty realizatorów ograniczone były przede wszystkim skromną przestrzenią, jaką dysponowali, ale również brakiem doświadczenia i wiedzy, czy taka forma teatru znajdzie swojego odbiorcę. Szybko jednak wszelkie obawy okazały się bezpodstawne, a pomysł oceniono jako niezwykle trafiony.

Prace zaczęły się dość skromnie. Pierwsze premiery prezentowane były w świetlicy Łódzkiego Okręgu Związku, przy ulicy Więckowskiego 13.

Miejsce raczej nie wygląda jak sala teatralna - pod ścianami biurowe szafy, w rogu przyrząd treningowy, nierozpakowane jeszcze po ostatniej przeprowadzce paczki. Jedynie ustawione $\mathrm{w}$ rzędach krzesła przypominają widownię. $\mathrm{Z}$ przodu wolne miejsce, gdzie jest stolik i krzesła dla aktorów ${ }^{15}$.

- tak wspominała Wrzesińska przestrzeń tych pierwszych spektakli. Ale pomimo takiej prowizorycznej aranżacji teatru, a także nie bacząc na fatalną pogodę, hulający wiatr, sypiący śnieg i lodowiska na chodnikach (pierwsze spektakle prezentowane były późną jesienią i zimą) kilkadziesiąt osób przyszło, aby wziąć udział w tym niecodziennym wydarzeniu. Cykl prezentacji rozpoczęła jedna z najpopularniejszych komedii teatralnych na świecie, autorstwa kanadyjskiego autora, aktora, scenarzysty i producenta teatralnego Bernarda Slade'a - Za rok o tej samej porze oraz jej kontynuacja - Po latach o tej samej porze. Publiczność przyjęła je owacyjnie, potwierdzając to, co wielokrotnie podkreślały inicjatorki zdarzenia, że odbiór sztuki zależy od inteligencji i poczucia humoru widza, a nie od tego, czy ktoś widzi, czy nie.

I tak w niecodziennym miejscu - sali PZN - najmocniej oddziaływały dowcipy autora dotyczące wad wzroku. Gdy George opowiadał o żonie, która zarzucając mu impotencję, mówi: „Myślałam, że jako księgowy jako pierwszy stracisz wzrok”, niewidomi słuchacze zanosili się ze śmiechu ${ }^{16}$.

Odbiorcy spektaklu nie szczędzili artystom wyrazów wdzięczności, jak notowała Wrzesińska: „Żywo reagują na to, co dzieje się przed nimi, śmieją się, [...

15 Teresa Wrzesińska, Teatr Czytany, „Pochodnia. Magazyn Społeczny Polskiego Związku Niewidomych” 2006, nr 4(824), s. 12-13, http://pochodnia.pzn.org.pl/ artykul/6219-teatr_czytany.html (dostęp: 7.05.2017).

16 Leszek Karczewski, Widzieć, stysząc, „Gazeta Wyborcza - Łódź” (9 lutego 2006). 
widać, że sztuka ogromnie im się podoba. A na koniec, jak w prawdziwym teatrze, są burzliwe oklaski na stojąco i róże dla aktorów i reżyserki”"17.

Po kolejnych premierach Ewa Pilawska podkreślała, że publiczność świetnie odbiera propozycje Teatru, jest wprawdzie bardzo wymagająca, ale przede wszystkim obdarzona ogromnym poczuciem humoru. W czasie grania znakomicie skonstruowanej farsy Marca Camolettiego Weekend na farmie odbiorcy nie powstrzymywali się nawet od wygłaszanych spontanicznie, na gorąco, recenzji: „Boże, jaki to świetny spektakl!” oraz dzielenia się własnymi przekonaniami: „Nigdy się nie ożenię!”. Te żywiołowe reakcje sprawiły, że Teatr nie mógł przestać realizować kolejnych premier, a ogromne zainteresowanie, jakim cieszyły się następne spektakle sprawiło, że przeniesiono je do specjalnie przystosowanego foyer Teatru Powszechnego, w którym budowana była scena i ustawiana widownia. Warto przywołać relację z kolejnego spektaklu, zamieszczoną w lokalnej prasie:

W środę o godz. 13.00 trzeba było dostawić krzesła w foyer. Sztuka Przyszłości nie da się zmienić to ósmy spektakl przygotowany przez Ewę Pilawską z myślą o niewidomych. Publiczności co premierę przybywa [...]. Jerzy Milczak opuścił tylko jeden spektakl. Tym razem przyszedł do Powszechnego z Andą, psią przewodniczką, owczarkiem niemieckim, która spała podczas spektaklu. [...] Jak ocenia Teatr Czytany? - To znakomity pomysł. Gdy narrator mówi, kto wchodzi i z której strony, łatwo sobie wszystko wyobrazić. Przedstawienie z żywymi ludźmi w tej samej przestrzeni co widzowie, to zupełnie inna jakość niż słuchowisko. Szkoda tylko, że Teatr Czytany jest tak rzadko ${ }^{18}$.

Od 2013 roku, w ramach projektu, premiery zostały przeniesione na nowo uruchomioną Małą Scenę Teatru Powszechnego. Starając się sprostać oczekiwaniom odbiorców projektu, każdego roku Teatr ubiega się o jego dofinansowanie przez sponsorów i o granty z Ministerstwa Kultury i Dziedzictwa Narodowego. Dzięki uzyskanemu wsparciu współfinansuje przejazdy autokarowe zorganizowanych grup osób niewidomych i słabowidzących spoza Łodzi. Zainteresowanie projektem jest bowiem tak duże, że do Teatru zgłaszają się ośrodki nie tylko z całego województwa, ale i z różnych stron Polski. Do tej pory w projekcie uczestniczyli widzowie m.in. z Sieradza, Warszawy, Leszna i Poznania. Od dwóch sezonów Teatr rozwija też swój projekt z myślą o osobach, które ze względu na stan zdrowia lub inne przeszkody nie są w stanie dotrzeć do teatru. Specjalnie dla nich, wspólnie

17 Teresa Wrzesińska, Teatr Czytany..., s. 13.

18 Leszek Karczewski, Na premiere z psim przewodnikiem, „Gazeta Wyborcza - Łódź” (14 grudnia 2007). 
z Radiem Łódź, Teatr przygotowuje zapisy audio kolejnych premier, które następnie prezentowane są na antenie łódzkiej rozgłośni PR i w internecie.

Realizacja kolejnych premier Teatru dla niewidomych... sprawia obu stronom wielką radość, choć ten oryginalny projekt stanowi również duże wyzwanie dla zespołu aktorskiego. Forma przygotowywanych tu spektakli, dająca aktorom duże możliwości rozwoju, otwiera przestrzeń niezwykle rzetelnej pracy, pozwalającej szlifować warsztat. „Naprawdę nie ma żadnej różnicy w odbiorze gry aktorskiej - mówił po pierwszych realizacjach Grzegorz Pawlak, aktor Teatru Powszechnego. - Taka forma przedstawienia teatralnego przypomina nieco pracę w słuchowisku radiowym, chociaż tutaj nie ogranicza nas mikrofon, do którego trzeba grać”. A partnerująca mu w tych pierwszych przedstawieniach Karolina Łukaszewicz dodaje: „Trzeba wszystko stworzyć w wyobraźni widza. Prawie nie ma tak pomocnych nam rekwizytów, ruch też jest ograniczony, ale nas to niezwykle rozwija"19.

Pilawska od początku istnienia Teatru dla niewidomych ... mocno podkreśla, że forma ta niewiele ma wspólnego ze słuchowiskiem. Dlatego też unika dziś nazwy Teatr Czytany. Reżyserce zależy bowiem przede wszystkim na tym, by uzyskać, oparte na dialogu, specyficznie teatralne napięcie między publicznością a sceną. Jak wielokrotnie powtarzała:

Zawsze interesuje nas uniwersalny aspekt teatru, który pozwala na przeżywanie czegoś wspólnie. Także wątpliwości pojawiających się w samym człowieku, którego światopogląd i doświadczenie zostają skonfrontowane ze sztuką, a z drugiej strony, który konfrontuje swoją wrażliwość i reakcje z wrażliwością i reakcjami innych osób na widowni. Tego rodzaju prawdy scenicznej nie da się osiągnąć bez skonstruowania szkicu postaci i zarysowania sytuacji ${ }^{20}$.

Dlatego też próby projektu wyglądają jak „normalne” przygotowania do teatralnej premiery. Odbywają się próby stolikowe, analizowany jest tekst, „szkicowane" postaci, określane ich wzajemne zależności i motywacje, budowany jest zarys sytuacji. Wykorzystana jest symboliczna dekoracja i kostiumy. Specyfiką pracy jest natomiast to, że trzeba przykładać ogromną wagę do szczegółu. Jak mówi Ewa Pilawska, która wyreżyserowała (społecznie) wszystkie premiery Teatru dla niewidomych i stabo widzacych:

Przede wszystkim powinnam podziękować za cierpliwość tej wyjątkowej publiczności. Przy pracy nad Teatrem dla niewidomych ... uczyłam się i ciągle się uczę. $\mathrm{Na}$

19 Rozmowy autorki z Karoliną Łukaszewicz i Grzegorzem Pawlakiem.

20 Rozmowa autorki z Ewą Pilawską. 
pewno popełniłam wiele błędów. Ale wsłuchuję się z uwagą w to, co mówi publiczność i jej uwagi są dla mnie ogromnie ważne. Mam nadzieję, że doświadczenia zebrane podczas kolejnych realizacji procentują. Pamiętam, że od początku wiedziałam, iż wymaga on zróżnicowanej ścieżki dźwiękowej, że to, co nam, osobom widzącym, wydaje się oczywiste i prowokuje reżysera do skrótów i skreśleń w egzemplarzu, dla osób niewidomych już oczywistym nie jest. Na przykład w tekście Petera Quiltera Duety jest taki moment, kiedy bohaterka wskazuje na swoje piersi i nazywa je „azymutami”. Ja didaskalia, które ten gest, to działanie opisywały, usunęłam, bo wydawały mi się zbędne. A po spektaklu usłyszałam, że niewidomi nie odczytali tego żartu, po prostu nie wiedzieli o co chodzi. Mąż jednej z pań zasiadających na widowni wytłumaczył jej dopiero, co się dzieje. Pewnie nie ustrzegłam się kilku podobnych błędów. Dlatego wszelkie uwagi ze strony widowni są dla mnie bardzo cenne. Z drugiej strony zdaję sobie sprawę, że zbyt długie didaskalia zwalniają tempo akcji, wpływają na rytm spektaklu. Dlatego śmieję się, że przy pracy mam zawsze poczucie, iż jedną ręką skreślam, podczas gdy drugą się od tych skreśleń powstrzymuję ${ }^{21}$.

Osoba niewidoma w kinie czy w teatrze słyszy dialogi, dźwięki, ale nie widzi scenografii, gestów bohaterów, ich wyrazu twarzy czy noszonych przez nich kostiumów. Dlatego lektor musi wszystko to opisać - sprawnie, między dialogami. Słowem musi uzupełnić ruchomy obraz. Oczywiście odbieranie teatru to rzecz bardzo indywidualna. Odbiór zależy również od stopnia utraty wzroku, a także od tego, kiedy osoba niewidoma straciła wzrok, a co za tym idzie, czy dysponuje utrwaloną pamięcią wyobrażeń wzrokowych ${ }^{22}$. Ale swoista przewaga osób niewidomych nad widzącymi polega też na tym, że mają one wyostrzone inne zmysły - dotyk, słuch, a czasem nawet wrażliwość na słowo. Dawno już bowiem zaobserwowano, że niewidomi potrafią dostrzegać w otoczeniu takie cechy przedmiotów i zjawisk oraz ich różnice, których nie zauważają osoby widzące. Zmysły osób niewidzących potrafią precyzyjniej wychwytywać i różnicować płynące $\mathrm{z}$ otoczenia bodźce, choć nietrudno tu o mitologizację i falsyfikację tego stanu i uleganie stereotypowym przekonaniom ${ }^{23}$.

Biorąc pod uwagę predyspozycje i sposób odbioru rzeczywistości przez osoby niewidome, spektakle prezentowane w Teatrze dla niewidomych... zostały wzbogacone o wszelkie elementy odbierane przez pozostałe zmysły.

21 Ibidem.

22 Por.: Tadeusz Majewski, Psychologia ... , passim.

23 Por.: Danuta Gorajewska, Fakty i mity o osobach z niepetnosprawnościa, Biblioteczka Przyjaciół Integracji, autor i red. serii eadem, wyd. 2 popr. i uzup., Stowarzyszenie Przyjaciół Integracji, Warszawa 2009, http://www.niepelnosprawni.pl/files/www.niepelnosprawni.pl/public/rozne_pliki/fakty_i_mity_2009 (dostęp: 10.09.2017). 
Z przedstawionych już wcześniej rozważań wynika jasno, że w przypadku braku wzroku wartość kompensacyjna zmysłu słuchu jest bardzo duża. Rolę tego zmysłu trzeba jednak widzieć i oceniać w połączeniu z pozostałymi zmysłami, zwłaszcza ze zmysłem dotyku, kinestetycznym. $Z$ uwagi na to, że słuch należy do teleanalizatorów - jego rola w tym zestawie jest dość istotna. Pod tym względem jest on najważniejszym zmysłem, albowiem pozostałe teleanalizatory (zmysł węchu, wibracji) nie przedstawiają dla niewidomego tak dużej wartości ${ }^{24}$. Jednak i te brane są pod uwagę przy realizacjach Teatru dla niewidomych... I tak np. podczas prezentacji sztuki Anne Marie Etienne Przyszłości nie da się zmienić aktorzy obierali na scenie pomarańcze, o których parę razy wspomina się w tekście, tak by ich zapach unosił się w foyer. Przy innych przygotowywano potrawy o charakterystycznym aromacie lub też aktorka rozpylała w powietrzu perfumy, o których opowiadała. Na scenie pojawiają się prawdziwe szklanki i kieliszki, do których nalewane są płyny, aktorzy przerzucają strony książek lub szeleszczą gazetami, jeśli wynika to z tekstu. Wiele dźwięków, które nie pochodzą od aktorów, jest specjalnie wcześniej nagranych, tak by każdy wskazany w tekście element dźwiękowy wybrzmiał na scenie. Jednak najtrudniejszym momentem w pracy nad Teatrem dla niewidomych ... jest „ogranie” egzemplarza scenariusza, z którym grają aktorzy, a który niekiedy zastępuje oczy partnera.

Teatr dla niewidomych... nie zamyka się $\mathrm{w}$ jednej przestrzeni inscenizacyjnej, poszukuje wciąż nowych rozwiązań. Niekiedy mamy do czynienia z rozbudowanymi - na swój sposób - elementami scenografii, kostiumów czy choreografii. Aktorzy przemieszczają się po scenie, lub - jak to miało miejsce w przypadku Niezwykłego domu pana A, czyli skradzionych dźwięków, w którym realizatorom zależało na wykreowaniu opisanej przez Alana Ayckbourna przestrzeni z ukrytymi w rozmaitych miejscach dźwiękami, takiej, w którą niejako wciągnięte byłyby dzieciaki na widowni - poruszali się po całej przestrzeni foyer i pomiędzy widzami. Z kolei przy 21. premierze aktorzy byli statyczni, siedzieli przy stolikach umieszczonych na scenie, trzymając w ręku jedynie egzemplarze, z których czytali. Taką formę wymusił w tym wypadku sam tekst. Farsa, jaką jest Weekend na wsi Marca Camolettiego, jest bardzo trudnym gatunkiem do zaprezentowania w Teatrze dla niewidomych ..., dlatego Pilawska uznała, że ważniejsza będzie dla niej praca nad relacjami między postaciami. Artyści mają bowiem do czynienia z niezwykle wrażliwym, uważnym i wyczulonym na fałsz odbiorcą i najważniejsze jest odpowiednie rozłożenie akcentów. „Otrzymanie informacji słownych zastępuje niewidomemu nabywanie wielu osobistych bezpośrednich doznań dotyczących właściwości i zjawisk otaczającego

24 Tadeusz Majewski, Psychologia ..., s. 61. 
świata" $25 . \mathrm{W}$ zakresie odbioru niewidomi wykorzystują mowę dźwiękową, czyli zespół bodźców akustycznych, nie tylko jako środek porozumiewania się z otoczeniem, ale także jako źródło poznania pewnych cech osoby mówiącej, np. płci, wieku, a nawet pewnych stanów psychicznych - stanu przygnębienia, zadowolenia, radości. Dla niewidomych kompensacja werbalna ma szczególne znaczenie dla poznania przedmiotów niedostępnych poznaniu pozawzrokowemu. Niewidomi posiadają umiejętność specyficznego rozumienia słów, oddającego ich treść wzrokową, są to tzw. wyobrażenia surogatowe ${ }^{26}$.

\section{Wyjątkowe pokazy}

Kolejne propozycje Teatru dla niewidomych... są specjalnie przygotowanymi premierami, a niekiedy prapremierami. Nie są to więc przystosowane do potrzeb prezentacji dla osób z dysfunkcją wzroku spektakle z repertuaru Teatru Powszechnego, a spektakle zrealizowane specjalnie dla nich. Tak było m.in. w przypadku Weekendu na wsi Marca Camolettiego, Roszady Pawła Mossakowskiego czy Matki brata mojego syna Juliusza Machulskiego, których pokazy w ramach projektu poprzedzily prapremierowe wystawienie na deskach teatru. Wybór tekstów determinują również potrzeby i upodobania widowni.

Jak mówi Ewa Pilawska:

Bardzo wzięłam sobie do serca uwagę, którą usłyszałam zdaje się po realizacji Przerżnać sprawę Davida Mameta. Usłyszałam wtedy, że publiczność bardzo prosi, aby

25 Zofia Sękowska, Kształcenie dzieci niewidomych, Państwowe Wydawnictwo Naukowe, Warszawa 1974, s. 76.

26 Wyobrażenia te mają charakter wyobrażeń wytwórczych (fantazyjnych) i prowadzą do typowych, prawidłowych skojarzeń między przedmiotem a ich niedostępnymi niewidomym cechami, np. barwami (błękitne niebo, zielona łąka, czerwona krew), albo pomiędzy przedmiotami a ich niedostępnymi częściami (kościół z wieżą, dom z kominem, samochód $\mathrm{z}$ silnikiem). Wyobrażenia surogatowe mogą powstać na tle bodźców właściwych, a więc dotykowych (np. wyobrażenie sobie człowieka - mężczyzny, kobiety, dziecka - na podstawie wysokości, barwy jego głosu). Wyobrażenia surogatowe odnoszące się do światła i barw powstają tylko na tle bodźców niewłaściwych, czyli np. kojarzenie sobie barwy z barwą dźwięków ( barwy żółtej z barwą dźwięku wydawanego przez klarnet, barwy zielonej z barwa tonów fletu itd.). Por.: Tadeusz Majewski, Mamusiu, co to jest czerwony?, http://tyfloserwus.trakt.org.pl/viewpage.php?page_id=150 (dostęp: 5.05.2018). 
były to spektakle pogodne, z happy endem i dużą dawką optymizmu, będące rozrywką w najczystszej formie. Szczególnie na początku miałam ambicje, żeby jak najbardziej zróżnicować repertuar naszych spotkań. Chciałam zacząć od łatwiejszych w realizacji, dwuosobowych sztuk, ale marzyłam, żeby później sięgnąć po inny rodzaj poczucia humoru i po inny typ teatru. Tym niemniej zawróciłam z tej drogi, kiedy po raz kolejny usłyszałam, że widownia oczekuje czegoś innego. W przypadku Teatru dla niewidomych ... mówimy o wyjątkowych, jednorazowych pokazach, dlatego muszę przyznać, że repertuar układam tu w ogromnej pokorze i w głębokim wsłuchaniu w potrzeby i oczekiwania odbiorców. W dużej mierze są to sztuki angielskie, które mają świetnie napisane didaskalia. Porównywałam wiele tekstów, jednak często brakowało mi w nich tych rozbudowanych opisów, które w tym konkretnym przypadku są dla nas najważniejsze. Oczywiście można się pokusić o dopisanie didaskaliów, ale to jest już ingerencja w materię dramatu. Dlatego wolę korzystać z tekstów, które oryginalnie spełniają nasze potrzeby. Taka była też idea Teatru Czytanego. Nie jest to wprowadzenie osób niewidomych na spektakl, do którego - jak $\mathrm{w}$ przypadku audiodeskrypcji - dodajemy specjalnie przygotowane opisy miejsc i sytuacji, ale przygotowane z myślą o niewidomych przedstawienie ${ }^{27}$.

Teatr dla niewidomych ... zyskał - to, co najważniejsze - zaufanie i przychylność osób niewidzących, ale zwrócił także uwagę Związku Niewidomych. W październiku 2007 roku Prezydium Związku uhonorowało Ewę Pilawską Złotą Odznaką Honorową PZN „za stworzenie pierwszego Teatru Czytanego dla osób niewidzących i słabowidzących, za jego kontynuację i artystyczny rozwój" 28 . W 2009 roku w Belwederze odbyły się uroczyste obchody Międzynarodowego Dnia Osób Niewidomych, w których wzięło udział wielu znamienitych gości, m.in. Pierwsza Dama Pani Maria Kaczyńska i prezydent Europejskiej Unii Niewidomych Lord Colin Low. Podczas uroczystości Ewa Pilawska otrzymała wyróżnienie za swój autorski projekt ${ }^{29}$.

27 Premierom towarzyszą programy teatralne, które dzięki współpracy i pomocy Biblioteki Niewidomych oraz Specjalnego Ośrodka Szkolno-Wychowawczego nr 6 drukowane są także w wersji napisanej w języku Braille’a. Na dwóch kartach formatu A4 zamieszczane są podstawowe informacje o autorze i prezentowanej sztuce.

28 Treść uzasadnienia przyznania Ewie Pilawskiej, Dyrektor Teatru Powszechnego w Łodzi, Złotej Odznaki Honorowej Polskiego Związku Niewidomych.

29 We wręczonym jej liście gratulacyjnym czytamy: „Z okazji Międzynarodowego Dnia Osób Niewidomych prosimy przyjąć serdeczne podziękowania i gratulacje za Pani pracę na rzecz osób z niepełnosprawnością, w szczególności osób niewidomych i słabowidzących. Wyrażamy nasze uznanie i szacunek za przygotowanie i reżyserowanie spektakli dla osób z dysfunkcją wzroku. Dostęp do dóbr kultury pozwala osobom 
Teatr Powszechny pozostaje w stałym kontakcie nie tylko ze Związkiem Niewidomych, ale i ze Specjalnym Ośrodkiem Szkolno-Wychowawczym nr 6 im. mjr. Hieronima Baranowskiego, czyli Łódzką Szkołą dla Słabo Widzących i Niewidomych „Na Dziewanny”. Z myślą o niewidomych i słabowidzących młodych widzach w grudniu 2009 roku TP przygotowal premierę: Niezwykly dom pana A, czyli skradzione dźwięki Alana Ayckbourna. Sztuka brytyjskiego komediopisarza to opowieść o tym, że wiara w miłość rodzica nie tylko uskrzydla małego człowieka, ale i dodaje mu odwagi w najtrudniejszych momentach, pomagając wejść do ciemnego pokoju czy pokonać strach przed nieznanym. Specjalnie dla tej wyjątkowej dziecięcej publiczności warszawska firma Kalimba zaprojektowała i uszyła zabawki edukacyjne. Nieprzypadkowo były to pluszowe psy, bo najbliższym przyjacielem głównej bohaterki sztuki i towarzyszem jej przygód jest właśnie pies - Niewiem. Maskotki wręczone widzom w przerwie między aktami sztuki były w jaskrawych, kontrastujących kolorach - by umożliwić ich lepsze poznanie dzieciom słabowidzącym - a dodatkowo każdy pluszowy zwierzak miał na szyi dźwięczący dzwoneczek. Autor sztuki Niezwykły dom pana A, czyli skradzione dźwięki zgodził się na prezentację sztuki pro bono. W realizację premiery włączyła się również tłumaczka Elżbieta Woźniak, która nie po raz pierwszy udostępniła Teatrowi przekład sztuki swojego autorstwa. Od tego wydarzenia Ewa Pilawska przynajmniej jedną premierę Teatru dla niewidomych $i$ stabo widzacych $\mathrm{w}$ sezonie przygotowuje specjalnie $\mathrm{z}$ myślą o młodszej widowni. W ramach projektu swoje prezentacje miały prapremierowe teksty, które później Teatr Powszechny w Łodzi zrealizował w ramach edukacyjnego programu Dziecko w sytuacji. Spektakle przygotowywane dla Teatru dla niewido$m y c h$... stanowią prawdziwe „pokonywanie kolejnych barier” - i przez aktorów, i przez publiczność. Ta ostatnia pokonuje tych barier o wiele więcej, bowiem zanim pozna sztukę - musi poznać drogę do teatru.

\section{Obopólna korzyść}

$\mathrm{Z}$ czysto teatralnego punktu widzenia można by przekornie zapytać: po co czytać i grać sztukę w teatrze osobom niewidomym. Co ma $\mathrm{z}$ tego teatr? Odpowiedź jest prosta: widza, kolejnego odbiorcę. Dla wielu osób uczestniczących w premierach Teatru dla niewidomych... (zarówno dzieci, jak i osób dorosłych)

z niepełnosprawnością wzrokową na pełniejszą integrację społeczną, a jednocześnie stanowi bogate źródło pięknych doznań możliwych dzięki kontaktowi ze sztuką”. 
jest to nierzadko pierwsze spotkanie $\mathrm{z}$ teatrem. Najmłodsi pytani o swoje oczekiwania i wrażenia po premierze Niezwykłego domu... przyznawali, że podchodzili do wizyty w teatrze dość sceptycznie: „Podobało mi się, choć początkowo myślałem, że będę się nudził i będę zasypiał. A tu proszę taka niespodzianka!” - opowiadał dziennikarce jeden z uczestników ${ }^{30}$.

Dzięki projektowi Teatr zyskuje jednak coś, co w języku sztuki nazywa się „nową przestrzenią artystyczną”. Konieczna jest bowiem zupełnie inna gra, inaczej rozłożone są aktorskie akcenty. Z jednej strony publiczność zapraszana jest na Małą Scenę, co od razu prowokuje do grania „blisko widza”. Jest to zresztą zgodne $\mathrm{z}$ tendencjami współczesnego teatru, który coraz częściej zaprasza na kameralną widownię dla kilkudziesięciu czy stu osób. Taki teatr zabiega o stworzenie niemal intymnej atmosfery spotkania, w której prowadzi z widzem dia$\log$, otwiera się na sztukę w rozmaitych jej wymiarach i odważnie zadaje pytania o człowieka, o wszystko to, co go dotyczy, i o świat, w którym żyje. Jak wielokrotnie podkreśla Ewa Pilawska, zarówno przy okazji premierowych realizacji Teatru Powszechnego, jak i komentując prezentacje Międzynarodowego Festiwalu Sztuk Przyjemnych i Nieprzyjemnych (który również zainicjowała i nadal organizuje) - nie jest ważne, jaki gatunek posłuży jako medium dla podjętej rozmowy. Równie przejmująco co tragedia mogą bowiem oddziaływać gatunki komediowe. Taki teatr wymaga bardzo realistycznego, ale „nienachalnego" aktorstwa, w którym każdy, nawet najmniejszy, gest czy element mimiki jest sygnałem dla widza. Ta bliskość zmusza do subtelniejszego kreślenia postaci, do budowania ich głębi psychologicznej i sygnalizowania jej odbiorcy w sposób „dyskretny”. Z drugiej zaś strony szczególna publiczność Teatru dla niewidomych ... wymaga wyrazistego, jednoznacznego przekazu, bliższego raczej graniu na scenie $\mathrm{z}$ dużą widownią. To zmusza aktorów do znalezienia swoistego „złotego środka”, który pozwoli odbiorcom „dostrzec” cechy charakterystyczne bohaterów sztuki, lecz będzie się wystrzegal ich karykaturowania. Wymaga to od aktorów ogromnej dyscypliny, ale i koncentracji. Trudno bowiem utrzymać wiarygodne emocje i nie ukryć się za maską przerysowanego gestu i postawionego głosu, kiedy zamiast twarzy partnera ma się przed sobą egzemplarz sztuki, a kolejne, także te najbardziej intymne wyznania, przerywane są przez kwestie tzw. Didaskaliusza (pełniącego poniekąd funkcję antycznego didaskalosa), który opisuje wygląd sytuacji i charakter zachodzących działań. Bo to, co w sposób naturalny wypływa z ciała aktora i jest $\mathrm{w}$ jego obecności na scenie niemal nierozerwalnie sprzężone $\mathrm{z}$ emocjami towarzyszącymi wymawianym słowom, zostaje tu wyodrębnione i nazwane. Wszystko

30 Por. fragment programu TVP3: Łódzkie Wiadomości Dnia, grudzień 2009 roku, reporter Krystyna Piaseczna, https://www.youtube.com/watch?v=pQ noliBVy8 (dostęp: 20.07.2017). 
to zmusza więc ciało do większej dyscypliny. Każdy gest, każde działanie, nawet najbardziej banalne czy wydawać by się mogło - odruchowe, zostaje podporządkowane tekstowi i musi być zgodne z tym, co zapisane w didaskaliach i co zostanie przekazane odbiorcy. Daje to oczywiście aktorom okazję do pokazania swego warsztatu. Reżyserująca wszystkie premiery Ewa Pilawska sięga po nowe sposoby inscenizacji, także wówczas, gdy wystawia farsy. Pozbawia aktorów „farsowych” kostiumów od razu charakteryzujących postać. Ubrani we współczesne stroje zostają posadzeni przy stolikach, co odbiera im również możliwość wykorzystania - tak często używanych $\mathrm{w}$ farsowym teatrze - np. przerysowanych gestów czy chwytu bezustannego zmieniania miejsc, będących motorem ciągu komicznych nieporozumień. Tu komizm musi zrodzić się z intonacji głosu, z realistycznej, wiarygodnej prezentacji emocji i działań, oraz z takiego prowadzenia dialogu, który pozwoli uwierzyć widzom w ów ciąg niewiarygodnych wręcz nieporozumień czy - świadomych i nieświadomych - zamian ról. Okazuje się, że farsa nabiera dzięki temu szlachetności. Że pozbawiona ciągłej gonitwy po scenie i przysłowiowego „ślizgania się na skórce od banana” nadal może wywoływać u widzów salwy śmiechu.

Teatr dla niewidomych ... niesie zatem obopólne korzyści, udostępnia tę dziedzinę sztuki osobom, które do tej pory były jej pozbawione, i otwiera teatr na nowe artystyczne przestrzenie. Ale co najważniejsze: buduje sytuację rzeczywistej społeczno-kulturowej wspólnoty, opartej na wzajemnej otwartości i akceptacji, co tak bliskie jest współczesnemu, ponowoczesnemu myśleniu o sztuce teatru, będącej przede wszystkim przestrzenią dialogu i spotkania. Wpisuje się on również w ujęcie hermeneutyczne (m.in. w koncepcje jednego z głównych myślicieli XX wieku Paula Ricoeura), zgodnie z którym siebie samych możemy zrozumieć tylko poprzez konfrontację z tym, co inne, czy też z absolutną innością Innego, jaką „proponuje myśl dialogiczna choćby w wydaniu Levinasa. [... ] Tylko poprzez swoiste i niepowtarzalne wydarzenie, jakim jest dialog, można zrozumieć Innego. Do tego zaś niezbędne jest zawieszenie swoich ocen na jego temat i otwarte nasłuchiwanie"31. I takim otwartym nasłuchiwaniem potrzeb drugiej osoby jest właśnie Teatr dla niewidomych i stabo widzących.

Do momentu oddania książki do druku Teatr Powszechny w Łodzi zrealizował łącznie 68 premier w ramach cyklu (wszystkie społecznie wyreżyserowała dyrektor Ewa Pilawska). Teatr i dyrektor Ewa Pilawska otrzymali za jego realizację

31 Marcin Orliński, Ogólność i inność w dyskursie nauk humanistycznych, www. racjonalista.pl/kk.php/s,3882 (dostęp: 7.05.2018). 
kolejne wyróżnienia i nagrody, m.in. Odznaczenie „Przyjaciel Niewidomych” i tytuł „Placówka Kultury Województwa Łódzkiego”, przyznawane przez Fundację Szansa dla Niewidomych.

\section{Bibliografia}

Bligham Dorothy, Analiza pewnych aspektów rozwoju niewidomego dziecka, „Materiały Tyflologiczne”, Polski Związek Niewidomych, Warszawa 1980.

Ciborowski Mateusz, Pod lupa: Chodź, opowiedz mi świat, „Pochodnia. Magazyn Społeczny Polskiego Związku Niewidomych” 2010, nr 4(871), http://pochodnia. pzn.org.pl/artykul/311-pod_lupa_chodz_opowiedz_mi_swiat.html (dostęp: 10.09.2017).

Gorajewska Danuta, Fakty i mity o osobach z niepełnosprawnościa, Biblioteczka Przyjaciół Integracji, autor i red. serii eadem, wyd. 2 popr. i uzup., Stowarzyszenie Przyjaciół Integracji, Warszawa 2009.

Integracja osób niepetnosprawnych $w$ edukacji i interakcjach spotecznych, red. Zdzisław Kazanowski, Danuta Osik-Chudowolska, Uniwersytet Marii Curie-Skłodowskiej, Lublin 2003.

Jancewicz Justyna, Sztuka nie tylko dla sztuki, „Pochodnia Magazyn Społeczny Polskiego Związku Niewidomych” 2009, nr 6(861), http://pochodnia.pzn.org.pl/ artykul/102-sztuka_nie_tylko_dla_sztuki (dostęp: 10.09.2017).

Karczewski Leszek, Na premierę z psim przewodnikiem, „Gazeta Wyborcza - Łódź” (14 grudnia 2007).

Karczewski Leszek, Widzieć, stysząc, „Gazeta Wyborcza - Łódź” (9 lutego 2006).

Krause Arkadiusz, Człowiek niepetnosprawny wobec przeobrażeń spotecznych, Impuls, Kraków 2005.

Labisko Agnieszka, Integracja $w$ teatrze. Rozmowa $z$ Tomaszem Strzymińskim, http:// www.teatry.art.pl/!rozmowy/iwte.htm (dostęp: 29.07.2017).

Majewski Tadeusz, Psychologia niewidomych $i$ niedowidzacych, Państwowe Wydawnictwo Naukowe, Warszawa 1983, https://pl.scribd.com/ document/132636388/ Majewski-Tadeusz-Psychologia-niewidomych-i-niedowidz\%C4\%85cych-rtf (dostęp: 29.07.2017).

Orliński Marcin, Ogólność i inność w dyskursie nauk humanistycznych, www.racjonalista. $\mathrm{pl} / \mathrm{kk} . \mathrm{php} / \mathrm{s}, 3882$ (dostęp: 7.05.2018).

Przybylski Stefan, Refleksje nad barierami występującymi przy wdrażaniu integracji osób niepetnosprawnych w Polsce na początku nowego tysiąclecia, [w:] Integracja osób niepetnosprawnych wedukacji i interakcjach społecznych, red. Zdzisław Kazanowski, Danuta Osik-Chudowolska, Uniwersytet Marii Curie-Skłodowskiej, Lublin 2003, s. 15-26.

Rzedzicka Krystyna D., Inny w edukacji, [w:] Dylematy pedagogiki specjalnej, red. Alicja Rakowska, Jolanta Baran, Wydawnictwo Naukowe Akademii Pedagogicznej, Kraków 2000. 
Sękowska Zofia, Kształcenie dzieci niewidomych, Państwowe Wydawnictwo Naukowe, Warszawa 1974.

Szymańska Barbara, Audiodeskrypcja „obraz stowem malowany”, http://www.audiodeskrypcja.pl/obrazSlowemMalowany.html (dostęp: 29.07.2017).

Wrzesińska Teresa, Teatr Czytany, „Pochodnia. Magazyn Społeczny Polskiego Związku Niewidomych” 2006, nr 4(824), s. 12-13, http://pochodnia.pzn.org.pl/ artykul/6219-teatr_czytany.html (dostęp: 7.05.2017).

Żuraw Hanna, Udział osób niepetnosprawnych $w$ kulturze, [w:] Człowiek niepetnospraw$n y w$ społeczeństwie, Materiały II Kongresu TWK, Warszawa, 1-2 października 1983 roku, red. Aleksander Hulek, Polskie Towarzystwo Walki z Kalectwem, Warszawa 1986.

\section{Netografia}

(dostęp: 7.05.2017)

http://pochodnia.pzn.org.pl

www.audiodeskrypcja.pl

www.biblioteka-pzn.org.pl

www.integracja.org

www.niepelnosprawni.pl

www.ofcom.org.uk

www.racjonalista.pl

www.rzezba-oronsko.pl

www.trakt.org.pl

www.tvp.pl 